\title{
The devil, 666 and the COVID-19 vaccine
}

Author:
Boitumelo B. Senokoane ${ }^{1}$
Affiliation:
'Department of Philosophy,
Practical and Systematic
Theology, College of Human
Sciences, University of
South Africa, Pretoria,
South Africa
Corresponding author:
Boitumelo Senokoane,
senokbb@unisa.ac.za
Dates:
Received: 15 June 2021
Accepted: 23 Aug. 2021
Published: 17 Nov. 2021
mobile phone or
to read online.
How to cite this article:
Senokoane, B.B., 2021 'The
devil, 666 and the COVID-19
vaccine', HTS Teologiese
Studies/Theological Studies
77(1), a6924. https://doi.
org/10.4102/hts.v77i1.6924
Copyright:
C 2021. The Authors.
Licensee: AOSIS. This work
is licensed under the
Creative Commons
Attribution License.

This article aims to engage the statement of the South African Chief Justice Mogoeng Mogoeng where he made a direct link between the Covid-19 vaccine, the devil and triple-six. The article will try to locate his argument; but above that to engage the statement in relationship to the biblical text of Revelation 13:11-18, which is where the original statement is. There will be an attempt to understand the context of the Book of Revelation and the context of Revelation 13:11-18. Some Christian and churches have been claiming that the vaccine contains foetal tissues or microchips or are construing associations between vaccines ingredients and the devil. Others talk about how coronavirus vaccines and masks contain or herald the 'mark of the beast', a reference to an apocalyptic and or a passage from the Book of Revelation that suggests that the Antichrist will test Christians by asking them to put a mark on their bodies. The article will further engage the relationship between science and religion and or reason and faith.

Contribution: The article contributes to the theological discourses of interpretation, translation and understanding of the biblical texts in their contexts. The article engages the method of theology of reading the text from behind.

Keywords: 666; beast; Covid-19; context; religion; science; faith; reason.

\section{Introduction}

The years 2020-2021 can be classified and categorised as one of the worst in recent human history. This is because the outbreak of the Covid-19 pandemic severely affected the lives of human beings. There have been several attempts by different countries to formulate a vaccine to fight Covid-19; but this has not happened without challenges and suspicions. As if it is not enough, the reported consequence of vaccine triggering immune response has found support in scientific and religious theories that are anti-vaccine.

Dr Sherri Tenpenny, a Cleveland doctor and anti-vaccine advocate made a connection amongst vaccine, 5G internet and metal objects sticking to the bodies of vaccinated people. While giving testimony at an Ohio House Health Committee, she argued:

'Im sure you've seen the pictures all over the internet of people who have had these shots and now they're magnetised. They can put a key on the forehead. It sticks. They put spoons and forks all over them and they stick, because now we think that there's a metal piece to that...There's been some sort of an interface, 'yet to be defined' interface, between what's being injected in these shots and all of the 5G towers'.

Individuals such as Kemokoenawamathole Msholozi Mathole has speculated and posted on his Facebook page, stating:

$[T]$ hey force everyone to be indoors and switch off the electricity so that they can spread poison during the nights to make people sick. They want to force magnets on everyone and claiming that there is a strong wave of kovid. (31 May 2021)

On the religious side, the Chief Justice of South Africa, Mogoeng Mogoeng (2021), in December, led a prayer at Thembisa hospital saying:

[I]f there be any (Covid-19) vaccine that is the work of the devil meant to infuse 666 in the lives of the people, meant to corrupt their DNA...may it be destroyed by fire. (p. 1)

In this article, I will try to understand the view of Mogoeng but also engage his context as a lawyer and a spiritual man who resides both in the scientific and religious worlds or as a man subscribing to both reason and faith. I will then engage the historical-political background of the Book of Revelation, specifically chapter 13: 11-18. This I will do to try to understand Mogoeng, his world; but above all to give a proper context to his remarks and of the text of Revelation. I will do this because of my view that context is everything, and everything is interpreted through context. 


\section{The context of Revelation 13:11-18}

The number 666, mentioned by Mogoeng, is found in the Book of Revelation (13:11-18) as follows:

\section{The Beast out of the Earth}

${ }^{11}$ Then I saw a second beast, coming out of the earth. It had two horns like a lamb, but it spoke like a dragon. ${ }^{12}$ It exercised all the authority of the first beast on its behalf, and made the earth and its inhabitants worship the first beast, whose fatal wound had been healed. ${ }^{13}$ And it performed great signs, even causing fire to come down from heaven to the earth in full view of the people. ${ }^{14}$ Because of the signs it was given power to perform on behalf of the first beast, it deceived the inhabitants of the earth. It ordered them to set up an image in honour of the beast who was wounded by the sword and yet lived. ${ }^{15}$ The second beast was given power to give breath to the image of the first beast, so that the image could speak and cause all who refused to worship the image to be killed. ${ }^{16}$ It also forced all people, great and small, rich and poor, free and slave, to receive a mark on their right hands or on their foreheads, ${ }^{17}$ so that they could not buy or sell unless they had the mark, which is the name of the beast or the number of its name.

${ }^{18}$ This calls for wisdom. Let the person who has insight calculate the number of the beast, for it is the number of a man. ${ }^{[a]}$ That number is 666 .

This text has a particular historical and political context. I must caution, of course, that 'preterist interpreters seek to ground any fulfilment of Revelation in events in the history of the first or second century A.D. Such attempts have proven unsuccessful' (MaCpherson 2005:267). But it must be clear that the context of Revelation and others goes beyond. MaCpherson (2005:269) argued that 'it is helpful to recognize that language describing the mark of the beast is more rooted in the O.T than in first-century conditions' and these include 'sign commandments' which include circumcision (Gn 17:11); the Feast of Unleavened Bread and the law of the firstborn, both of which are signs on the hand and forehead (Ex 13:9, 16) and the Sabbath (Ex 31:13, 17; Ezk 20:12, 20).

Context is very important in reading, translation, interpretation and understanding of a text. The simple definition of context is the background information surrounding a subject. When studying a literary text, context can apply to either historical context: what was taking place around the time a text was written, and how does this impact our reading of the text? One can look at historical, cultural, social, religious or political contexts, but in a broader sense, context usually comprises all the mentioned aspects. The reason that context is important when studying literature is that it gives an idea about what was going on around the time the text was produced.

As far as the Bible is concerned, every book, letter and epistle of the Bible emerge in the course of history, and justify the necessity to read the Bible in context. We need to read it in its historical context inclusive of its world, the author and the original audience. In order to fully understand a source, it must be placed within the context of the time period in which it was produced. Contextualising a historical source involves paying attention to the people who produced it, their period and what was going on during that time, and how what was going on may have influenced the produce of the source. It also involves understanding how the source's language, concepts and terms were used within that historical context, since meaning change over time. Context understanding increases the readers' credibility as it demonstrates the readers' willingness to understand the source and its time period on its terms instead of the reader. The relationship between the reader and the text is indeed dynamic and without understanding the context of the source, it might even be worse. For example, according to Nystrand, Greene \& Wiemelt (1993):

[T] he meaning of any text is neither (a) found in the writers intentions, which according to cognitive models of writing, the writer 'translates' into text, nor (b) embodied in the text itself, as proposed in such formalist accounts of exposition as Olson's (1977) doctrine of autonomous text. Rather, texts are said merely to have a potential for meaning, which is realized only in use, for example, when a text is read (even by the writer). This meaning is dynamic, which is to say, it evolves over the course of reading...it is not exactly the same from reader to reader; and it manifests the cultural and ideational assumptions readers bring to the text. This is not to say that readers completely determine the meaning of the text; instead, whatever meaning is achieved is a unique configuration and interaction of what both the writer and reader bring to the text. (pp. 298-299)

I need to qualify the dynamism of a meaning with a 'but'. But being dynamic must not mean a distortion and laziness to understand the context of a source. Understanding the historical context of a primary source is critical for understanding the attitudes and influences that shape the creation of the primary source. If not placed into historical context, a primary source's true meaning might be misinterpreted. The limits of not understanding context limit the reader to appreciate the world of the source. Biblical context is important because it can help prevent wrong interpretations of Scripture, faulty theology and confusion while reading God's Word. When we ignore the context, we miss the original meaning or intent.

With this in mind, we should then appreciate that Revelation 13:11-18 has its historical context, that can shed light on the background of the source, and eventually, the interpretation. We can furthermore explore the biblical techniques for understanding the conundrum including: gematria, arithmetic, symbolic and riddle-based solutions, and trace the concern of the author and his audience.

Mogoeng was specific in his diagnosis or interpretation, he spiritually linked the vaccine with number 666 that John describes as that mark or the name of the beast.

In Revelation, John sees a beast rising out of the sea, summoned by the dragon on the seashore (12:17). The sea was a place of chaos, danger and evil for the Hebrews (cf. comment on 21:1). In fact, it is imperative to take into consideration that one of the contexts of Revelation 13:11-18 actually begins from Revelation 12 reading as follows: 
${ }^{12} \mathrm{~A}$ great sign appeared in heaven: a woman clothed with the sun, with the moon under her feet and a crown of twelve stars on her head. 'She was pregnant and cried out in pain as she was about to give birth. ${ }^{3}$ Then another sign appeared in heaven: an enormous red dragon with seven heads and ten horns and seven crowns on its heads. ${ }^{4}$ Its tail swept a third of the stars out of the sky and flung them to the earth. The dragon stood in front of the woman who was about to give birth, so that it might devour her child the moment he was born. ${ }^{5}$ She gave birth to a son, a male child, who 'will rule all the nations with an iron scepter'. ${ }^{\text {[a] }}$ And her child was snatched up to God and to his throne. ${ }^{6}$ The woman fled into the wilderness to a place prepared for her by God, where she might be taken care of for 1260 days.

${ }^{7}$ Then war broke out in heaven. Michael and his angels fought against the dragon, and the dragon and his angels fought back. ${ }^{8}$ But he was not strong enough, and they lost their place in heaven. ${ }^{9}$ The great dragon was hurled down - that ancient serpent called the devil, or Satan, who leads the whole world astray. He was hurled to the earth, and his angels with him.

${ }^{10}$ Then I heard a loud voice in heaven say:

Now have come the salvation and the power and the kingdom of our God, and the authority of his Messiah.

For the accuser of our brothers and sisters, who accuses them before our God day and night, has been hurled down.

${ }^{11}$ They triumphed over him by the blood of the Lamb and by the word of their testimony; they did not love their lives so much as to shrink from death.

${ }^{12}$ Therefore rejoice, you heavens and you who dwell in them!But woe to the earth and the sea, because the devil has gone down to you!He is filled with fury, because he knows that his time is short.

${ }^{13}$ When the dragon saw that he had been hurled to the earth, he pursued the woman who had given birth to the male child. ${ }^{14}$ The woman was given the two wings of a great eagle, so that she might fly to the place prepared for her in the wilderness, where she would be taken care of for a time, times and half a time, out of the serpent's reach. ${ }^{15}$ Then from his mouth, the serpent spewed water like a river, to overtake the woman and sweep her away with the torrent. ${ }^{16} \mathrm{But}$ the earth helped the woman by opening its mouth and swallowing the river that the dragon had spewed out of his mouth. ${ }^{17}$ Then the dragon was enraged at the woman and went off to wage war against the rest of her offspring - those who keep God's commands and hold fast their testimony about Jesus.

This text is equally important because its simple reading has problems. One such problem is identified by Lee (2001) arguing against certain interpretation in favour of a rereading and raising a question of a myth:

[C]ontemporary women's rereading of ancient myth is complicated by the alien worldview of the stories, enshrining values that women, since the Enlightenment, have been extensively reshaping. The issue is critical within the JudeoChristian tradition, where myth provides a sacred canopy for socioreligious structure giving narrative framework to its life and buttressing its teaching and ritual. The question is whether and how we can revalorize ancient stories formed in an androcentric haven where every aspect of a woman's lifeoccupation, religious and political status, moral characteristics, relationships was laid down by the socioreligious systems and supported by its methodology. (p. 200)
The beast described in Revelation 13 is not soothsaying predictions of what is to be, but symbolic descriptions of what is already being experienced by the author and the community. Collins (1977) argued that:

$[P]$ erhaps the hardest won and most dearly held result of historical-critical scholarship on the Revelation to John is the theory that the work must be interpreted in terms of the historical context in which it was composed. Such an approach refers to the images of Revelation to contemporary historical events and to eschatological images current at the time. Probably, the most widely accepted conclusions of this approach are that the beast from the sea of a chap. 13 and the woman of the chap. 17 represent the Roman empire in some way. Such allusions to the contemporary ruling power raise the issues of the political perspective expressed in these references. There are no doubts on several ways in which that perspective might be elucidated. The one chosen here is the comparison of the political implications of the Revelation to John with those of Jewish writings and movements in the period immediately preceding the composition of Revelation, that is, the late Hellenistic and early Roman periods. (p. 241)

If this is then a consensus, we can therefore conclude that the author is concerned with the power of the Roman Empire. It should be noted that the Book of Revelation was written around $96 \mathrm{CE}$ in Asia Minor. The author was a Christian from Ephesus known as John the Elder. Ephesus was both the capital of the Roman province of Asia and one of the earliest centres of Christianity. This region would become a key area for the expansion of Christianity into the Roman Empire.

The Book of Revelation is difficult for modern people to read, but not so difficult for people in the ancient world who would have been accustomed to the complex nature of apocalyptic literature. The fact that an apocalypse was a common type of literature meant that it followed a certain conventional style, and people knew more about what to expect from it. Because of apocalyptic writing, these conventions would have seemed less strange and cryptic. Also, apocalyptic literature was almost always a kind of literature for 'insiders', that is to say, it was written for people who already knew something of the situation and of the symbols that were used to portray it. So, for that original audience of the Revelation of John, all these strange scenes would have been immediately intelligible. What the modern reader or biblical scholar has to do is to try to read the text with 'ancient eyes', by being informed about the way the literature worked and the situation out of which it came. This is how Revelation 13:17-18 should be read.

We must understand that the book of Revelation is a 'wartime literature', it comes out of war, it comes out of people who have been destroyed by war. There was war in Jerusalem, and it was the time of Mount Vesuvius, and the Roman Emperors who were ruling at the time. It was equally the time of Christian persecution. De Villiers (2017) argued:

$[A]$ lmost all the earliest authors were victims of Roman oppression and even persecution. The eschatological pronouncements of Victorinus, for example, who was martyred in 303, reflect his 
experiences during the persecution of Emperor Diocletian. He regarded Rome as Babylon. Similarly, Irenaeus identified the number 666 as Latinus and Rome, that is, as those 'who reign now'. (p. 341)

Therefore, many of the images in the book were disguised metaphors for images associated with the ruling powers in Rome.

Chapter 13, overall, contains four of the most iconic concepts contained in Revelation. The two 'beasts' described are the figures often referred to as the Anti-Christ and the False Prophet. The symbol mandated for all followers of Anti-Christ, administered by the False Prophet, is that mark of the beast, which is further related to the number 666. Sanders (1918) clarified the number of the beast 666 and argued:

[T] he Church Fathers explained them as prophetic and tried to discover the name of Anti-Christ from an interpretation of the mystical number. Irenaeus, Contra Haer. 5, 29-30 writing between 180 and 190 A.D., was the first, so far as we know, to busy himself with the problem. He was troubled by the fact that some manuscripts or writers gave number 616, but was sure that it was an error, as he had just shown to his own satisfaction that 666 was necessarily right, for the flood came in the 600th years of Noah and the image set up by Nebuchadnezzar was 60 cubits high and 6 cubits wide. He accordingly interpreted only the number 666. (p. 95)

The Greek term charagma, mark in Revelation 13:16 was most commonly used for imprints on documents or coins. Mainstream scholars interpret the Beast as a symbol for the Roman Empire, an image that conveys governmental control and the extended, evil reach of the empire in commerce. De Villiers (2017) continued to argue that:

[T]he chronologizing of Revelation's pronouncements can be traced to Julius Africanus (ca.160-240), whose work influenced Hippolytus and Lactantius in the third century, as well as many other Greek and Latin authors. These authors designed a world calendar that placed the end of the world in the year $500 \mathrm{CE}$. The calendar covered 6000 years, based on the six days of creation mentioned in Genesis 1, with one day representing 1000 years. The incarnation was set in the year 5500, which was thus 500 years before the end. After 6000, Christ's Parousia would take place, followed by a Sabbath rest of a thousand years. (p. 342)

Observing this background, Mogoeng could be correct to argue vaccine as a mark of the beast if the intent is to corrupt human life and DNA. However, the interpretation can equally be problematic if it solely spiritualised as it might lose the content of the Scripture. And Mogoeng is moving in a grey area of religion and science or faith and reason. This point is argued by me in the next subheading.

\section{Religion and science}

Bentley (2012:1) argues that 'generally speaking, it is not common for scientists to engage theologians in order to educate them, while evangelical Christians engage scientist in order to convert them'. This is a natural conflict inherent of both sciences, but equally a solution to our question and our discourse.

In this section, I will argue the relationship between religion and science or faith and reason. Let me start by arguing that Africans are hopelessly religious, however Mogoeng is not exonerated. We must understand and grasp that religion is our social reality, at least in Africa. The persistence of religion throughout the ages is the proof of its survival value. It has rendered undeniable services to an African and is still serving. Religion like other institutions has its roots in certain human needs. Hence, it was felt to be a necessity and continues to be so. If religion is construed as nothing but belief in superhuman force or power, it remains incompatible with science. If, on the other hand, it is understood as a kind of ethical philosophy serving the cause of humanity, then the two are compatible. Religion in Africa, in its real sense, is not conflicting with science. It is only the dogma or theology or the distorted version of religion that conflicts with science. If the religion respects and accepts the values of science and if science recognises and accepts the reality and necessity of religion, then there could be no conflict between religion and science. But above that, there is no separation of life in Africa. Life is wholistic. It must, therefore, be noted that the 'reality in religion is therefore defined by parameters of three notions: dualism, transcendence and personal/contextual spirituality' (Bentley 2012:9).

Broadly speaking, science concerns itself with the natural, and religion with the supernatural. Mogoeng is the South African Chief Justice, a lawyer by training but also a Christian. Like most South Africans, he finds himself living in the world of both reason and faith. I must equally indicate that some observe a natural conflict between science and religion while others do not. Sanda, Smarandoiu and Munteanu (2017) argued that the relationship between science and religion is not accidental saying:

$[B]$ orn in the bosom of natural philosophy, at the same time as metaphysics (The sixth century B.C.E), science grew and developed for a long period of time (until) the beginning of the fifth century B.C.E) in a close relationship with the religious belief. From this moment, the first signs of its emancipation and separation from theological thought gradually developed and eventually turned scientific inquiry into an autonomous and independent enterprise, which became more and more conspicuous during the Renaissance and the Reformation. (p. 1)

What is very clear from the argument is that religion and science have both the visible and invisible relation. They, sometimes, come together and at a certain point work separately. Making a distinction between science and religion, Cortes, Del Rio, \& Vigil (2015:4) stated; 'science results from man's attempt to understand the natural world, comprehend the universe to which he belongs, and thus explain to himself his longing for transcendence'.

Astapov (2019) argued that:

[T] he rational sphere of consciousness can be described by the following essential characteristics: the logical form, systematism, 
criticism, argumentation and transmission of concepts, expression of essential properties and qualities of cognised objects. The outlogical form of expression, spontaneity, dynamism, integrity and value accentuation are the characteristics of the irrational sphere of consciousness. The irrational sphere is formed by faith, experiences and sensory data, that is, by pre-rational psychics. However, it is not true to say that religious concepts do not have irrational elements. Despite the fact that conceptualisation implies rationalisation, the irrational elements continue their existence in other forms. (p. 3)

Rational decision-making favours objectivity and a formal process of analysis over subjectivity and intuition. The archetypal of rational decision-making assumes that the decision maker has full or perfect information about alternatives; it also assumes that they have the time, cognitive ability and resources to evaluate each choice against the others. The goal of philosophy is to assist with problemsorting. These problems can be ethical, epistemological, existential, metaphysical or conceptual. There are two central difficulties for the project of philosophical analysis such as an open-ended nature of philosophical debate. It is part of the very nature that it focuses on areas of disagreement and controversy, and it is extremely rare for philosophers to achieve consensus on any issue. If no philosophical theory is generally accepted, then no philosophical theory will be very helpful to people trying to work out what they should do when facing a real life problem, because we cannot know which philosophical theory is the right one with any degree of assurance.

It is important to note that religious faith has six specific features (at a minimum) that distinguish it from other sorts of faiths:

1. It is a faith in the reality of a supernatural being.

2. It is a faith dependent on processes and events in human life and in the world from activity of the supernatural being.

3. It is a faith in manifestations of the supernatural being in the environment. Accordingly, to religious consciousness, the supernatural is found in a miracle, that is, in an act of radical intervention of the supernatural in the order of nature, an act of interruption of natural and social laws.

4. It is faith in communicating with the supernatural and in the possibility of influencing the supernatural as a result of this communication.

5. It is a faith in the truth of the ideas, the doctrines and the theories of the supernatural.

6. It is a faith in the authority of some individuals (the prophets, the saints, the ministers of religious worship, etc) who communicate with the supernatural (Astapov 2019:3).

There are two main strategies that theists employ when responding to the evidentialist objection to belief in God. The first strategy is to argue against the second premise, the claim that there is insufficient evidence for the existence of
God. The second strategy is to argue against the first premise, the claim that belief in God is rational only if it is supported by sufficient evidence. Therefore, belief in God is considered irrational for two primary reasons: lack of evidence and evidence to the contrary. But, the proponents of evidence do not concede that reason itself alone is a fallible human tool for discovering truth or grasping reality. Although reason aims at the truth, it may fall short. In addition, rationality is more a matter of how one believes than what one believes.

So, belief in God is neither self-evident, evident to the senses, nor incorrigible. Therefore, belief in God, according to classical foundationalism, cannot properly be included among the foundations of one's rational beliefs. And, if it is not part of the foundations, it must be adequately supported by the foundational beliefs - that is, belief in God must be held on the basis of other beliefs and so must be argued to, not from.

Mogoeng does not see any conflict between science and region, but shares the view of Sanda et al. (2017) that:

[I] $\mathrm{f}$ the understanding of God is desired, then man must give up his natural reason in favor of faith, thereby gaining its natural reason too, reason can, thus, be used at maximum strength. In this way, reason is able to know its limits, thus being prevented from hardening itself. As a result, reason can now open itself to faith, and is getting spiritualized. Therefore, the knowledge acquired through the stability pattern of association between reason and belief (centered on supernatural Revelation) is a knowledge through faith, which exceeds natural rational knowledge (positive and negative) of God, but which further uses mostly rational terms (positive and negative) to express itself. (p. 3)

Like any other African, who is of course not colonised, Mogoeng moves from the premise that there is no conflict between religion and science. Perhaps, his premise could be that religion deals with how the world operates supernaturally. And for him, science then attempts to define the laws of nature and how they affect events. In his argument, he further advances an indirect argument that there will always be certain things that science cannot explain or understand; therefore, religion can make sense of them. Bentley (2012:1-2) summarised this argument stating that 'religious reality is not the same as scientific reality and vice versa'. The effects of God on nature are some of these things. Of course, miracles will then be defined as those occurrences which are outside the laws of nature. A religious person would say that they are actions of God, very properly so, and a scientist would say that he does not know how they happened. Mogoeng does not see any conflict between religion and science, but seems to suggest that the two should not be mixed. This might be contradictory, yet he moves between the two worlds as both inseparable and separate but '....there needs to be an acknowledgement that when religion and science interact, it must be based on specific and well-defined problems' (Bentley 2012:12).

We can further see Mogoeng's view as argued by Stein (1993) that: 
$[I] \mathrm{f}$ through faith a truth is reached that cannot be accessed by any other means, philosophy cannot deny facts of faith without relinquishing its claim as universal truth, and moreover, without risking its inherent knowledge being tainted by error; due to the organic interdependence of the truth, if separated from the core, any partial aspect of it will be poorly illuminated. Hence, the material dependence of philosophy on faith. Therefore, if man's highest certainty is inherent faith, and if accessible truth, it has to take ownership of faith. Such is the case when it accepts in itself the truths of faith, and even more, analyses all other certainties in the light of such truths of faith, as the ultimate criterion. This also accounts for a formal dependence of philosophy on faith.

The dependence of philosophy on faith is argued lucidly by Owens (1994):

$[W]$ ith its probative force drawn solely from premises accessible to the human mind's own inherent powers, Christian philosophy probes the divinely revealed truths under their naturally knowable aspects. From the apologetic or defensive angle, this type of philosophy is needed to meet rational queries one's-own or those of others-arising from religious doctrines, for instance, from the tenets of creation, divine providence, immortality of the spiritual soul or human destiny. On the positive side, Christian philosophy deepens the attraction of revealed doctrines in a way comparable to the enhancement given them by architecture, music, art and poetry in actual Christian life. (p. 167)

In conclusion, Mogoeng's view can be summed up as in the argument of Kagema (2014) that:

$[R]$ egion and Science may be diverse entities with divergent outlook, where science advocates a rational perception of things while the region believes in a word where faith and revelation prevail, but it would be wrong to regard them as enemies. They may have conflicting ideologies but Africa needs both of them. (p. 52)

\section{Conclusion}

Having grappled with the context of the Book of Revelation and that of Revelation 13:11-18, one has deducted that Mogoeng might have, on the one hand, understood the text but on the other might not have understood its context. My argument and conclusion are based on the statement that in his statement starting with 'if there be any vaccine that is of the devil', indicates uncertainty from his side. On him having had understood the context of the text as metaphors, and could have equally opted to use the same style of expression when making a link between 666 and DNA or between the vaccine and the devil. Metaphors are common and are used deliberately to infuse uncertainty. As much as metaphors can help illuminate a thought or scene, it can also help to give it a touch of mystery and could have been Mogoeng's intention. The other possibility is that he might have genuinely not understood the context of Revelation and used allegorical interpretation of the said text. Allegorical interpretation means that one sees the literal meaning of a text as a sign that points to a deeper reality like spiritual or Christological truth. This method assumes that the Bible has various levels and tends to focus on the spiritual sense that includes allegorical sense, the moral sense and the anagogical sense. But what is very clear is that Mogoeng can be located between to having understood the context of Revelation 13 and being deliberate by using metaphors, or that he did not understand and became lost in interpretation.

It is very important for readers of the text to appreciate the context of texts. Critical text appreciation is based on the analysis of text from several different perspectives. While novices at the art of analysis might think that thinking about the details of a text might make the text boring, in fact, text analysis helps with appreciating a work even more (or, appreciating it in the first place, if the work seems mysterious or boring).

\section{Acknowledgements Competing interests}

The author declares that he has no financial or personal relationships that may have inappropriately influenced him in writing this article.

\section{Author's contributions}

B.B.S. is the sole author of this article.

\section{Ethical considerations}

This article followed all ethical standards for research without direct contact with human or animal subjects.

\section{Funding information}

This research received no specific grant from any funding agency in the public, commercial or not-for-profit sectors.

\section{Data availability}

Data sharing is not applicable to this article as no new data were created or analysed in this study.

\section{Disclaimer}

The views and opinions expressed in this article are those of the author and do not necessarily reflect the official policy or position of any affiliated agency of the author.

\section{References}

Astapov, S.N., 2019, 'The contradictory unity of faith and reason in Christian theoretical thought', HTS Teologiese Studies/Theological Studies 75(4), a273. https://doi.org/10.4102/hts.v75i4.5273

Bentley, W., 2012, 'The problem of reality in the religion-science conversation: An African contribution', in C.W. du Toit (ed.), Knowing, believing, living in Africa: Perspectives from science and religion, pp. 21-34, Research Institute for Theology and Religion, Pretoria.

Collins, A.Y., 1977, 'The political perspective of the Revelation to John', Journal of Biblical Literature 96(2), 241-256. https://doi.org/10.2307/3265880

De Villiers, P.G.R., 2017, 'Reading the Book of Revelation politically', Stellenbosch Theological Journal 3(2), 339-360. https://doi.org/10.17570/stj.2017.v3n2.a15

Kagema, D.K., 2014, 'The relationship between religion and science in mission: Reflections from an African Christian perspective', Research on Humanities and Social Science 4(2), 46-54. 
Lee, D.A., 2001, 'The heavenly woman and the dragon: Rereading of Revelation 12', in F. Devlin-Glass \& L. McCreddden (eds.), Feminist poetics of the sacred: Creative suspicions, Oxford University Press, New York, NY.

MaCpherson, A., 2005, 'The mark of the beast as a "sign commandment" and "antiSabbath" in the worship crisis of Revelation 12-14', Andrew University Studies 43(2), 267-283.

Mathole, K.M., 2021, 'Kemokoenawamathole Msholozi Mathole', [Facebook], 31 May 2021.

Nystrand, M., Greene, S. \& Wiemelt, J., 1993, 'Where did composition studies come from? An intellectual history', Written Communication 10(3), 267-333. https:// doi.org/10.1177/0741088393010003001

Owens, J., 1994, 'The need for Christian Philosophy. Faith and philosophy', Journa of the Society of Christian Philosophers 11(2), 1. https://doi.org/10.5840/ faithphil199411219
Sanda, D.C., Smarandoiu, L.A. \& Munteanu, C., 1918, 'The dialogue between science and religion: A taxonomic contribution', Religions 8(3), 35. https://doi.org/10.3390/ rel8030035

Sanders, H.A., 1918, 'The number of the beast in Revelation', Journal of Biblical Literature 37(1/2), 95-99. https://doi.org/10.2307/3259148

Stein, E., 1993, Erkenntnis und Glaube, Herder, Freiburg.

Varkony, K., 2021, Cleveland doctor tells Ohio lawmakers COVID-19 vaccine can leave people magnetized, interfaced with $5 G$ towers, viewed 08 June 2021, from https://fox8.com/news/coronavirus/cleveland-doctor-tells-ohio-lawmakerscovid-19-vaccine-can-leave-people-magnetized-interfaced-with-5g-towers/.

Venter, Z., 2021, Covid-19: Charges against Chief Justice Mogoeng Mogoeng over 'devil 666' anti-vaccine stance, viewed 14 January 2021, from https://www.iol.co.za/ pretoria-news/news/covid-19-charges-against-chief-justice-mogoeng-mogoengover-devil-666-anti-vaccine-stance-c3fa8c22-bb44-4887-9a03-350492a91044. 